\title{
Military Expenditure Comparisons
}

\author{
Hans-Christian CARS, Jacques FONTANEL \\ In \\ Peace, Defence and Economic Analysis, \\ (Schmidt, C., F. Blackhaby ; Eds.) \\ Mac Millan, London, 1987.
}

One problem in the negotiation and verification of any possible international agreement on the reduction of military expenditure is the difficulty of determining common definitions and methods of evaluation and comparison. Various alternative methods of comparison are discussed and the work of a United Nations group dealing with these matters, including particularly the purchasing power parity method, is reviewed. It is concluded, that, given political will and reasonable availability of adequate and relevant information, the construction of useful instruments for international and chronological comparisons of military expenditure is feasible.

Un des problèmes de la négociation et de la vérification d'un éventuel accord international sur la réduction des dépenses militaires est la difficulté de déterminer des définitions et des méthodes d'évaluation et de comparaison communes. Diverses méthodes alternatives de comparaison sont examinées et les travaux d'un groupe des Nations unies chargé de ces questions, notamment la méthode de la parité du pouvoir d'achat, sont passés en revue. Il est conclu que, sous réserve d'une volonté politique et d'une disponibilité raisonnable d'informations adéquates et pertinentes, la construction d'instruments utiles pour les comparaisons internationales et chronologiques des dépenses militaires est possible.

Dépenses militaires, comparaisons inter temporelles, comparaisons internationales Military expenditures, inter temporal comparisons, international comparisons 


\section{BASIC PROBLEMS}

Basic problems would be to agree on common definitions and rules for the valuation, accounting and reporting of the military expenditures of negotiating parties. On that basis, generally acceptable methods would have to be applied for the assessment of each side's expenditures and for their comparison. The quality of such assessments and comparisons would of course depend very much on the availability of adequate and accurate information.

Comparisons of military expenditures would not only be of interest in the context of possible future negotiations but are also needed as a means of analysing the social costs of the current arms race. There are obviously great difficulties in estimating the real military expenditures of different states as the figures differ largely among the few well-known sources that are available in this field.' This is especially true with respect to the military expenditures of countries with a centrally planned economy, as reliable data-even in terms of national currencies - are hard to obtain from such countries. A further problem is to compare such data with those of other countries as given in their national currencies, bearing in mind the fact that existing "exchange rates often poorly reflect the relative domestic purchasing-power of national currencies.

1. In all countries military secrecy hampers the availability of information but to an extent that varies largely among the countries. While some of them are rather open with regard to their military expenditures, others are very restrictive leaving the field open for more or less pertinent guesses.

2. Information produced and assessments made by various institutes are not easily comparable because of differing definitions with regard to the concept of military expenditures. Such components as military aid, civil defence, paramilitary forces, pensions for former military personnel, etc., are treated in different ways. In some cases they are considered as parts of the military expenditures and in other cases they are left aside. Such differences must of course be taken into account when figures from different sources are compared with one another.

3. Results from nuclear and space research efforts may have important military applications although the projects may be considered as being of a basically civilian character. It is a matter of judgement how much of the costs of such efforts should be 
defined as military expenditures. This difficulty may also cause important differences when it comes to the assessment of military research expenditures of various countries.

4! For the comparison of military expenditures of freely convertible currency countries most sources use market exchange rates as a means of converting national expenditure data into US dollars. As exchange rates may change drastically in a rather short period of time, results depend heavily on the particular time for which the rates are selected. Thus, the choice of exchange rates may have an important impact on the comparisons of military expenditures among countries. A further complication is created by the fact that market exchange rates do not exist for all countries. In such cases some other rates must be used instead and for that purpose several different approaches can be adopted.

For reasons such as these the use of exchange rates for the comparison of military expenditures may produce different results and none of them per se may be more or less correct than any other.

In addition to this it should be noted that the use of exchange rates as a means of international expenditure comparisons is susceptible to producing arbitrary differences because of subjective choices. Moreover, exchange rates, whether they are set administratively or on an international currency market, often poorly reflect the relative purchasing-power of the respective currencies with regard to their various domestic uses. Thus, other methods or instruments are needed in order to obtain reasonably accurate comparisons of international volume.

\section{ALTERNATIVE METHODS OF COMPARISON}

For the purpose of comparisons of international military expenditure a number of alternative methods have been elaborated and applied by various institutes and independent scientists. In addition to the budgetary approach there is, inter alia, the so-called hardwaremethod by which industrial statistics are used as a basis for various attempts to assess the size and scope of a country's military sector, including the defence industry and its production potential.

Another method is the so-called building-block method. This is used by the American Central Intelligence Agency to estimate the hypothetical dollar costs of producing in the USA the Soviet armed 
forces, including the training of their manpower together with the procurement and maintenance of their weapon systems and other types of equipment. One of the shortcomings of this method, however, is that it tends to overvalue the Soviet military efforts, as these are estimated at prices prevailing in the USA, where the price structure is quile different from the one existing in the USSR. This means that factors that are relatively cheap and therefore widely used in the military sector of the USSR, such as manpower, get too heavy a weight, if differences in relative prices are not properly taken into account. $^{2}$

\section{THE WORK OF THE UNITED NATIONS}

Parallel to the many efforts made by various institutes and individuals to explore the world's military expenditures a good deal of work has also been devoted to this issue by the United Nations. Ever since 1973 when it was proposed to the United Nations General Assembly that the major powers should cut their military spending, successive expert groups appointed by the Secretary-General have devoted substantial efforts to the analysis of the above-mentioned problems. In a first stage these efforts resulted, inter alia, in the elaboration, ${ }^{3}$ testing, ${ }^{4}$ and adoption, ${ }^{5}$ by the United Nations of an international system for standardised reporting of military expenditures. Since the adoption of this system in 1980 , more than thirty countries from all major geographic regions and with different economic systems have participated in the system and reported their military expenditures to the United Nations.

In a subsequent stage the problems of comparing military expenditures were examined by a group of experts with a view to finding appropriate solutions. This group pointed to the purchasing-powerparity method as an interesting approach which should provide much better results in international comparisons than those obtained through the use of prevailing exchange rates. Although purchasing power parities (PPPs) had already been constructed for the comparison of different large economic aggregates such as gross domestic product, private consumption and total government expenditures, it was still an open question whether this method could be successfully applied to comparisons of military expenditures considering their particularities and the generally limited availability of data. The group also stated the need for specific military price indices, as it was 
shown that general price indices in several cases poorly reflect the
actual price changes in the military sector.

Based on its analysis of the problems related to international and intertemporal comparisons in general and with special regard to military expenditures the group suggested in its report to the Second Special Session on Disarmament in 1982 that a practical exercise should be undertaken with a view to assessing the feasibility of constructing military PPPs. ${ }^{6}$ It was also suggested that such PPPs should be constructed together with military price indices for those countries that would volunteer to participate.

\section{A PRACTICAL EXERCISE}

The General Assembly agreed and decided that a new exercise should be started in $1983 .^{7}$ The group that was entrusted with this task worked for two years in cooperation with eight countries and presented its final report to the Secretary-General in the summer of $1985 .{ }^{8}$ The countries participating in this exercise were Australia, Austria, Finland, Italy, Norway, Sweden, the UK and the USA.

As a result of its work, the group came to several conclusions. One of them was that the construction of 'useful instruments for intertemporal and international comparisons of military expenditures, i.e. military price indices and PPPs, is feasible, given a sufficient availability of relevant statistical information. ${ }^{9}$ The group also stated that the experience gained through the exercise had been limited by the fact that no developing or planned economy country had chosen to participate.

For many years military or defence price indices have been continuously constructed by several countries. As a consequence, the methods applied by the group for the purpose of intertemporal comparisons did not represent anything very new.

Concerning the international comparisons, however, the group's exercise was the first in which the PPP-method was applied to military expenditures. In addition to the technical-statistical problems which are generally related to international comparisons of different economic aggregates, the group also had to tackle a number of problems specifically related to military expenditures. Such problems for instance were caused by the secrecy surrounding military information, the difficulty in determining unit prices, the high degree 
of differentiation with regard to military equipment and construction, and the lack of market prices.

The general scarcity of data, particularly with regard to military hardware made it necessary for the group to proceed in stages requesting from each participant additional information that would match that previously obtained from one or more of the other countries. Efforts were also made to ascertain that the prices reported for different items were calculated in the same way by all countries. However, in spite of these efforts most of the submitted price data on procurement items could not be used, because the items were often too different to warrant meaningful price comparisons.

Because of the general scarcity of price data on procurement items and the difficulties inherent in finding matching pairs of such items the basis for the construction of procurement PPPs was rather meagre, particularly from a quantitative point of view. Thus, the results obtained and presented in the group's report might have been different, if more data had been available. ${ }^{10}$ The primary purpose of the exercise, however, was not to obtain infallible results but to examine the feasibility of the PPP-method for the comparison of military expenditures among countries. In the group's opinion it was demonstrated through the exercise that this method is applicable to military expenditures including military hardware and that good international comparisons are possible, given reasonable availability of data and provided necessary effort is made to select and collect the information.

Furthermore, the group concluded that military price indices and PPPs reflect the real value of military expenditures better than civilian indices and other measures, and that their use is, therefore, preferable for measuring and comparing real military expenditures in the context of international negotiations on agreements to reduce such expenditures. In such a context, countries might well be more willing to exchange among themselves more information on characteristics and prices of military goods and services compared with that which they are willing to provide under present circumstances.

A special problem which the group faced was the comparison of conscripted and enlisted soldiers. On the one hand, these two categories of military personnel can be supposed to fulfil about the same functions in the case of war. On the other hand, it is clear that conscripts undergoing the first part of their basic training are less skilled and experienced than the average professional soldier. Upon careful examination of this question the group finally decided to 
regard conscripts with a training of six months or more as being by and large comparable to average enlisted soldiers. Thus, total subsistence costs of such conscripts, including daily pay, food charges and costs of accommodation, were compared with the average salary of enlisted soldiers. On this basis purchasing-power parities were also constructed for this category of personnel for all participating states.

\section{THE RESULTS}

The results of the group's exercise as presented in its report can be described as follows:

(a) Military price indices were constructed for all participating states, both for their total military expenditures and for a great number of different expenditure categories and subcategories. These results as shown in Tables 12.1 and 12.2 were also compared with two types of general civilian price indices. These comparisons are presented in Table 12.3. Judging from Table 12.1 it is evident that there can be important differences among countries with regard to their rates of military price increases. In the case of the USA the strongest inflationary pressure seems to have come in the two years under consideration from the procurement sector. This was probably because of the quickly-growing demand for military goods and services at that time followed by shortages in the defence industry. As for the other countries their major cost categories did not show inflation rates that were very different from the average.

The results presented in Table 12.2 provide ample opportunity to analyse in detail the relative price increases of the different subcategories of one of the main cost categories, namely that of operating costs. For five of the eight countries prices of personnel - that is, salaries and wages - increased at a lower rate than prices of goods and services in the operating-cost category. In all but two countries salaries and wages of military personnel grew more slowly than those of civilian personnel.

As shown in Table 12.3 comparisons were made with defence price indices of some countries which are known to use a large amount of input data and very elaborate methods for the construction of such indices. As may be seen from the table some of the group's results came very close to those obtained through such national efforts. This is an interesting observation and it is worth noting that the group obtained its results by means of a simplified method using a relatively 


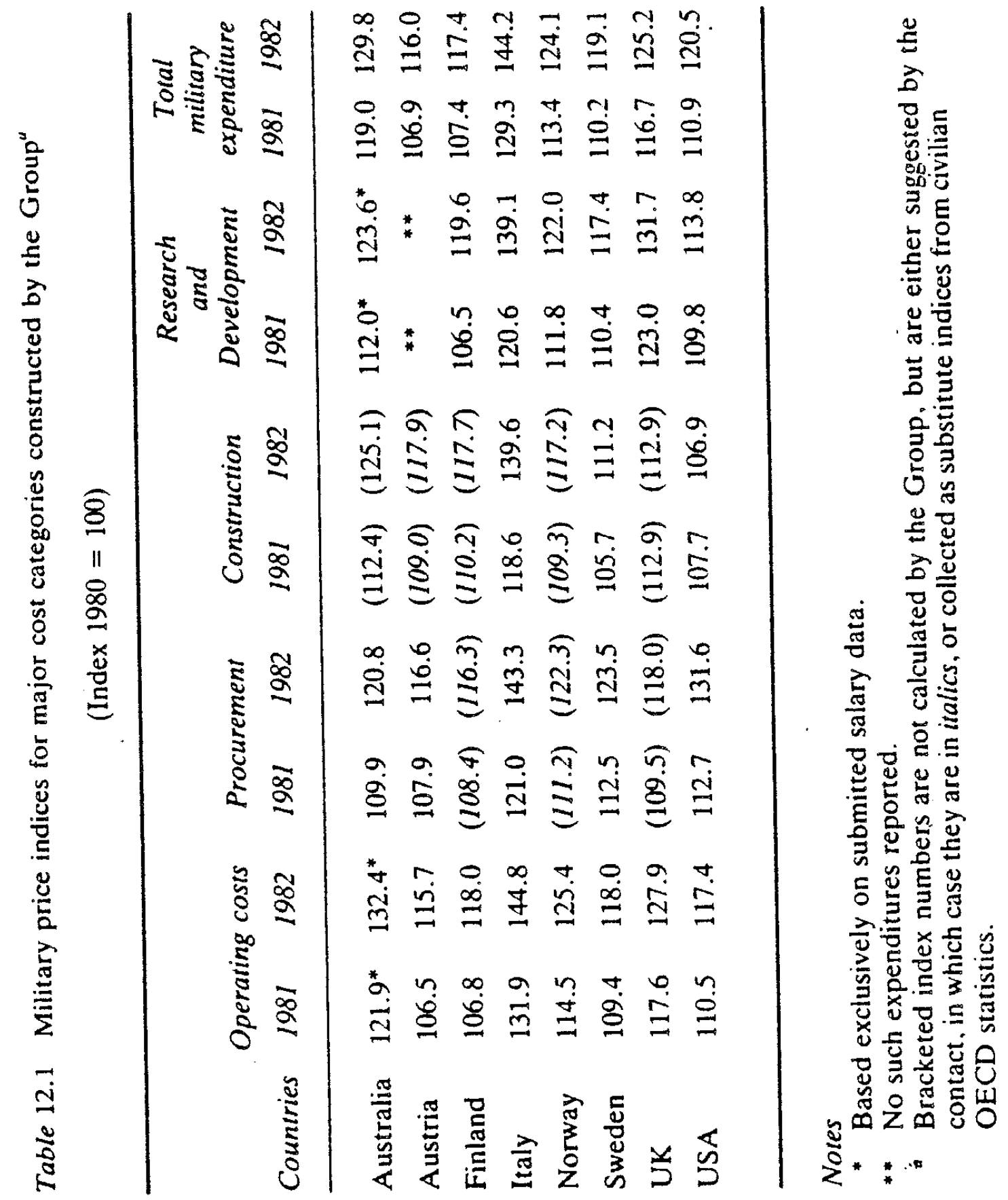


Table 12.2 Military price indices for subcategories of operating costs constructed by the
Group

(a) Price indices for personnel (Index 1980) $=100)$

\begin{tabular}{|c|c|c|c|c|c|c|c|c|}
\hline \multirow[t]{2}{*}{$\begin{array}{l}\text { Participating } \\
\text { States }\end{array}$} & \multicolumn{2}{|c|}{$\begin{array}{l}\text { Conscripted } \\
\text { persominel }\end{array}$} & \multicolumn{2}{|c|}{$\begin{array}{l}\text { Other military } \\
\text { persomed }\end{array}$} & \multicolumn{2}{|c|}{$\begin{array}{c}\text { Civilian } \\
\text { persommel }\end{array}$} & \multicolumn{2}{|c|}{$\begin{array}{c}\text { Tounl } \\
\text { persominel }\end{array}$} \\
\hline & & & 1981 & 1082 & 1081 & 19,82 & & 1982 \\
\hline Australia & - & - & 124.1 & 1.34 & 112 & & & 132 \\
\hline Austria & $I(x) .0$ & 120.7 & 107.1 & 114.4 & 1000 & 124.7 & 121.9 & 1,32 \\
\hline Finland & 112.1 & 1281 & & & 108.0 & 118.0 & 10.5 .5 & 117.0 \\
\hline Italy & & 126.1 & 102.1 & 112.0 & 106.3 & 116.1 & $104 . .3$ & 114.1 \\
\hline Wayy & 195.6 & 195.6 & 116.8 & 129.3 & 128.6 & 143.1 & 1.37 .7 & 147.5 \\
\hline Norway & 11.3 .1 & 124.3 & 111.9 & 122.3 & 114.3 & 124.1 & 112.8 & 123.2 \\
\hline Sweden & 105.4 & 110.9 & 106.3 & 112.5 & 106.7 & 113.6 & 106.3 & 112.5 \\
\hline UK & - & - & 110.4 & 117.2 & 117.8 & 124.5 & 112.9 & 119.7 \\
\hline USA & - & - & 108.4 & 119.2 & 109.8 & 115.9 & 108.8 & 118.1 \\
\hline
\end{tabular}

(b) Price indices for operations and maintenance $($ Index 1980$)=1(00)$

\begin{tabular}{|c|c|c|c|c|c|c|c|c|c|c|}
\hline \multirow[t]{2}{*}{ States } & \multicolumn{2}{|c|}{$\begin{array}{l}\text { Marerials } \\
\text { for } \\
\text { currenll use }\end{array}$} & \multicolumn{2}{|c|}{$\begin{array}{l}\text { Maimenance } \\
\text { and } \\
\text { repairs }\end{array}$} & \multicolumn{2}{|c|}{$\begin{array}{l}\text { Purchased } \\
\text { services }\end{array}$} & \multicolumn{2}{|c|}{$\begin{array}{l}\text { Rent } \\
\text { cossts }\end{array}$} & \multicolumn{2}{|c|}{$\begin{array}{c}\text { Tonal } \\
\text { operations } \\
\text { and } \\
\text { maintenance }\end{array}$} \\
\hline & & & 1981 & 1982 & 1981 & 1982 & 1981 & 1982 & & \\
\hline Australia & - & - & - & - & - & - & - & - & 121.9 & 132.8 \\
\hline Austria & 105.0 & 107.3 & 115.9 & 125.0 & 108.1 & 112.9 & 107.5 & 117.4 & 108.5 & 113.3 \\
\hline Finland & 111.4 & 125.6 & 107.8 & 118.4 & 110.5 & 12.3 .3 & 100.0 & 160.0 & 109.4 & 122.0 \\
\hline Italy & 121.8 & 145.8 & 119.7 & 137.1 & $118.7^{\circ}$ & 139.7 & 114.7 & 13.3 .3 & 119.9 & 1.39 .2 \\
\hline Norway & 118.0 & 126.3 & 118.2 & 129.5 & 118.3 & 142.1 & 111.5 & 123.8 & 117.9 & 129.7 \\
\hline Sweden & 116.8 & 1.35 .3 & 111.6 & 116.2 & 108.8 & 115.6 & 113.0 & 122.0 & 113.6 & 125.5 \\
\hline UK & 120.2 & 1.36 .6 & 133.6 & 145.9 & 117.7 & 124.9 & - & - & 122.8 & 137.0 \\
\hline USA & 116.4 & 116.4 & 110.2 & 115.9 & 110.9 & 116.4 & 107.7 & 114.2 & 113.4 & 116.2 \\
\hline
\end{tabular}




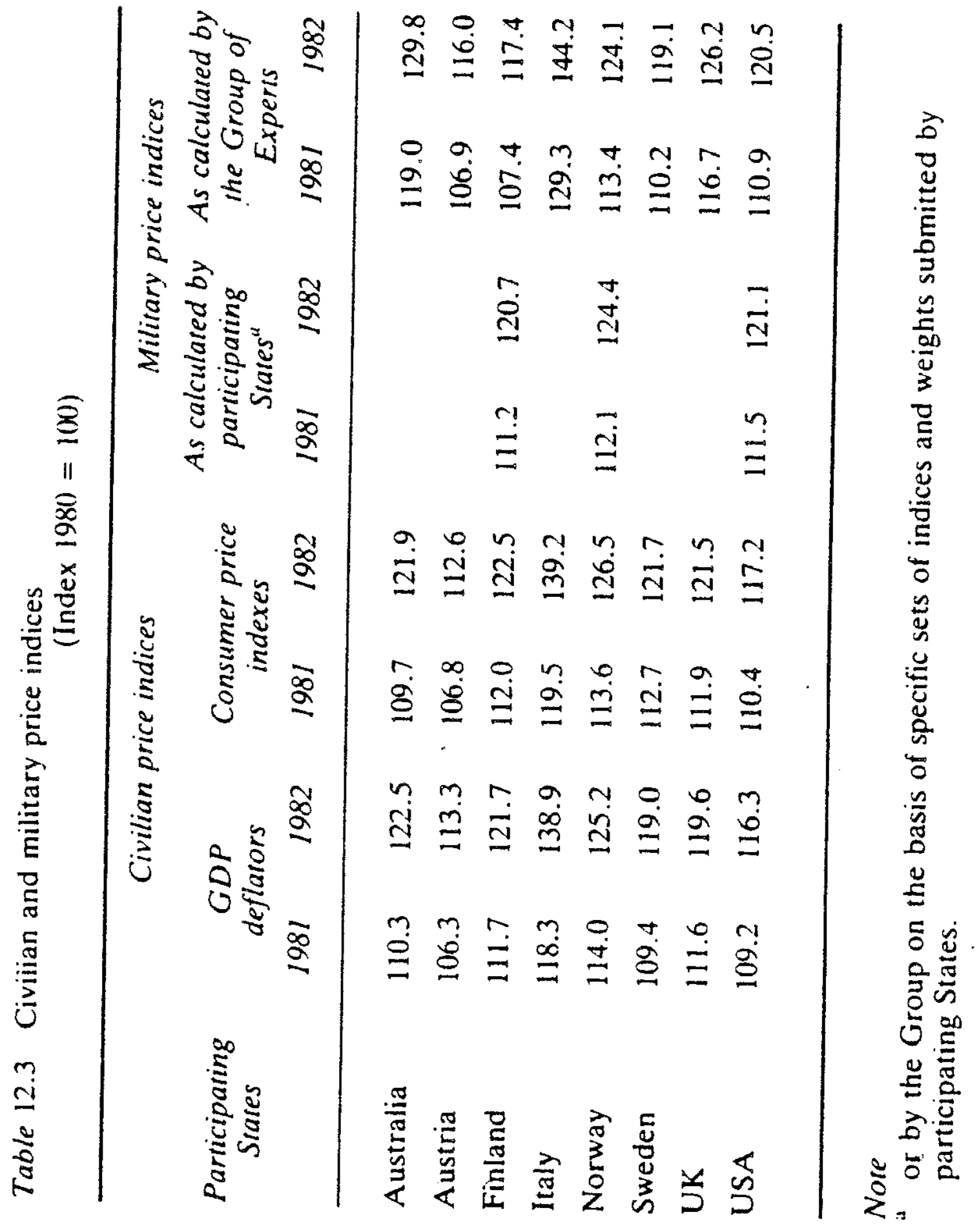


limited amount of information. This may be of special interest in the light of possible future negotiations on a reduction of military expenditures as a simple method and the use of easily verifiable data might greatly facilitate such negotiations.

For five of the eight countries military prices rose faster than the corresponding civilian price indices which seems to support the widely-held viewpoint that military expenditures have an inflationary impact on the economy. This notion is, however, contradicted by the results obtained for the three other participants which happen to be the Scandinavian countries. It is hard to say whether this is a coincidence or a sustained pattern for these three countries.

(b) Military purchasing-power parities were constructed for all participating states, both for their total military expenditures and for some expenditure categories and subcategories. These results are shown in Table 12.4. They are also compared-in Table 12.5 with exchange rates and a set of civilian purchasing-power parities as constructed by the Organisation for Economic Cooperation and Development (OECD). To achieve these results the group had to use a limited number of surrogate indices and parities, which were provided either by the participating states themselves or in some cases collected from other sources.

Concerning Table 12.4 there is one observation particularly worth mentioning and this is the very strong domestic purchasing-power of the dollar with regard to the category of procurement and construction. In view of the highly-developed US arms industry and its many technological advantages it is not surprising to find that the Americans get relatively more for their money in terms of weaponry and other types of military equipment than they get in terms of personnel and various kinds of those goods and services that fall within the operating-cost category. The extent to which this is really the case may not be accurately reflected by the results in Table 12.4 because of the limited number of comparable data mentioned earlier. However, the results strongly support the generally accepted hypothesis that the USA have a substantial cost advantage over other countries with regard to procurement items.

It may also be noted that the military personnel in Australia, Austria and the UK is relatively much more expensive than the civilian personnel, while the opposite is true for Finland. One might have expected military personnel to be relatively less expensive in countries which have conscription. However, the results presented in Table 12.4 do not give evidence of such a pattern. 
Table 12.4 Military PPPs of 1982 as constructed by the Group

(a) PPP' for total expenditures and major categories

\begin{tabular}{lrccc}
\hline $\begin{array}{l}\text { Participating } \\
\text { States }\end{array}$ & $\begin{array}{c}\text { Operating } \\
\text { costs }\end{array}$ & $\begin{array}{c}\text { Procurement } \\
\text { and } \\
\text { construction }\end{array}$ & $\begin{array}{c}\text { Research } \\
\text { and } \\
\text { developmemt }\end{array}$ & $\begin{array}{c}\text { Total } \\
\text { military } \\
\text { expenditures }\end{array}$ \\
\hline Australia & 1.37 & 2.60 & 1.14 & 1.45 \\
Austria & 11.77 & 51.44 & $1-$ & 13.56 \\
Finland & 3.17 & 9.38 & 4.91 & 4.00 \\
Italy & 567.00 & 2302.00 & 673.00 & 679.00 \\
Norway & 6.34 & 13.36 & 6.51 & 7.14 \\
Sweden & 6.24 & 11.63 & 5.37 & 7.10 \\
UK & 0.54 & 1.54 & 0.49 & 0.61 \\
USA & 1.05 & 0.89 & 1.05 & 1.00 \\
& & & & \\
\hline
\end{tabular}

(b) PPPs for subcategories of operating costs.

\begin{tabular}{lrrrr}
$\begin{array}{l}\text { Participating } \\
\text { States }\end{array}$ & $\begin{array}{c}\text { Military } \\
\text { personnel }\end{array}$ & $\begin{array}{c}\text { Civilian } \\
\text { personnel }\end{array}$ & $\begin{array}{c}\text { Operations } \\
\text { and } \\
\text { maintenance }\end{array}$ & $\begin{array}{c}\text { Total } \\
\text { operating } \\
\text { costs }\end{array}$ \\
\hline Australia & 2.02 & 1.02 & 0.99 & 1.37 \\
Austria & 13.58 & 7.34 & 12.97 & 11.77 \\
Finland & 2.49 & 4.35 & 4.41 & 3.17 \\
Italy & 493.00 & 552.00 & 906.00 & 567.00 \\
Norway & 5.69 & 5.51 & 8.28 & 6.34 \\
Sweden & 6.74 & 5.81 & 5.81 & 6.24 \\
UK & 0.73 & 0.32 & 0.57 & 0.34 \\
USA & 1.03 & 1.15 & 1.01 & 1.05 \\
& & & & \\
\hline
\end{tabular}

Vote: Based on data for construction items only. 


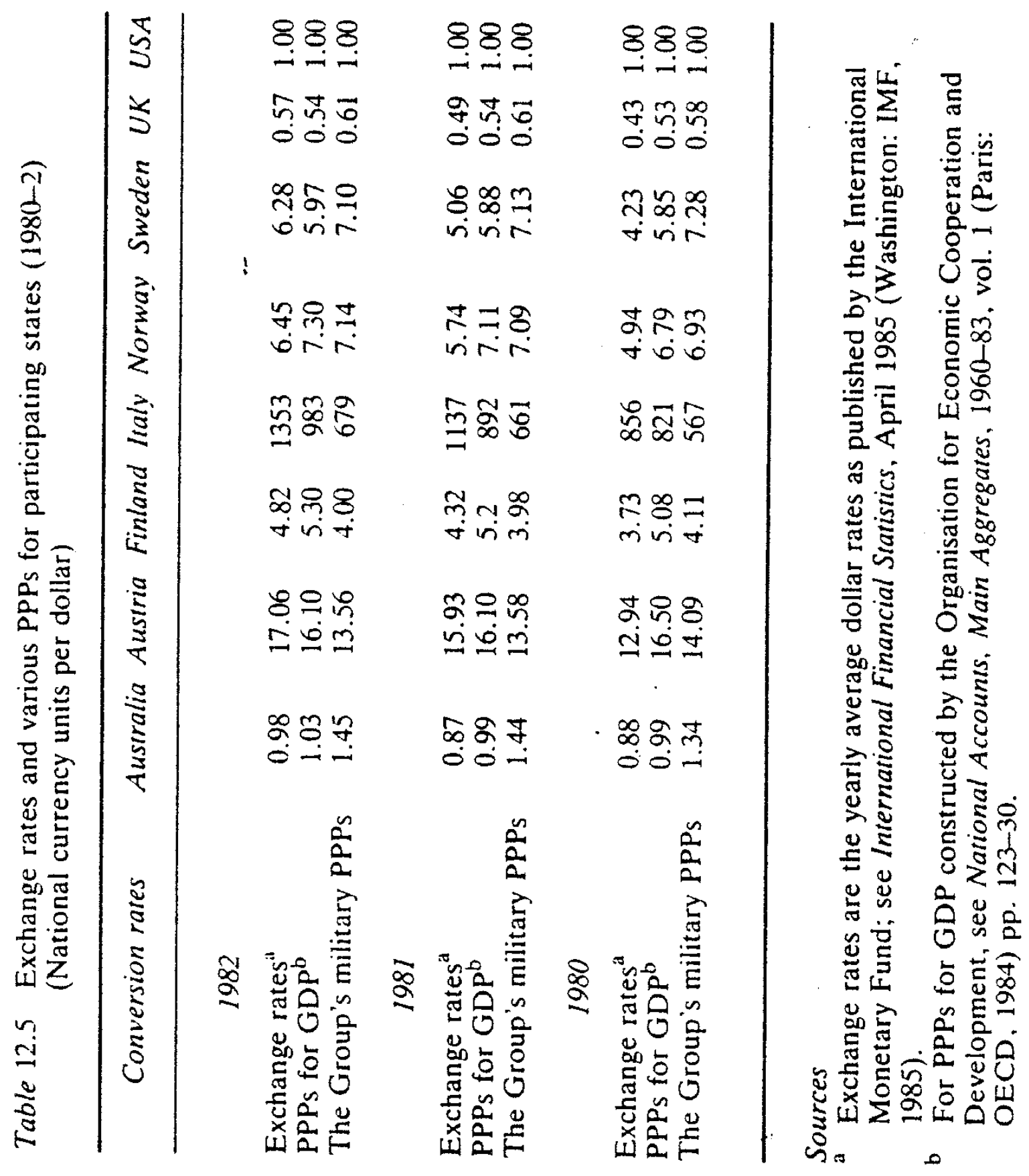




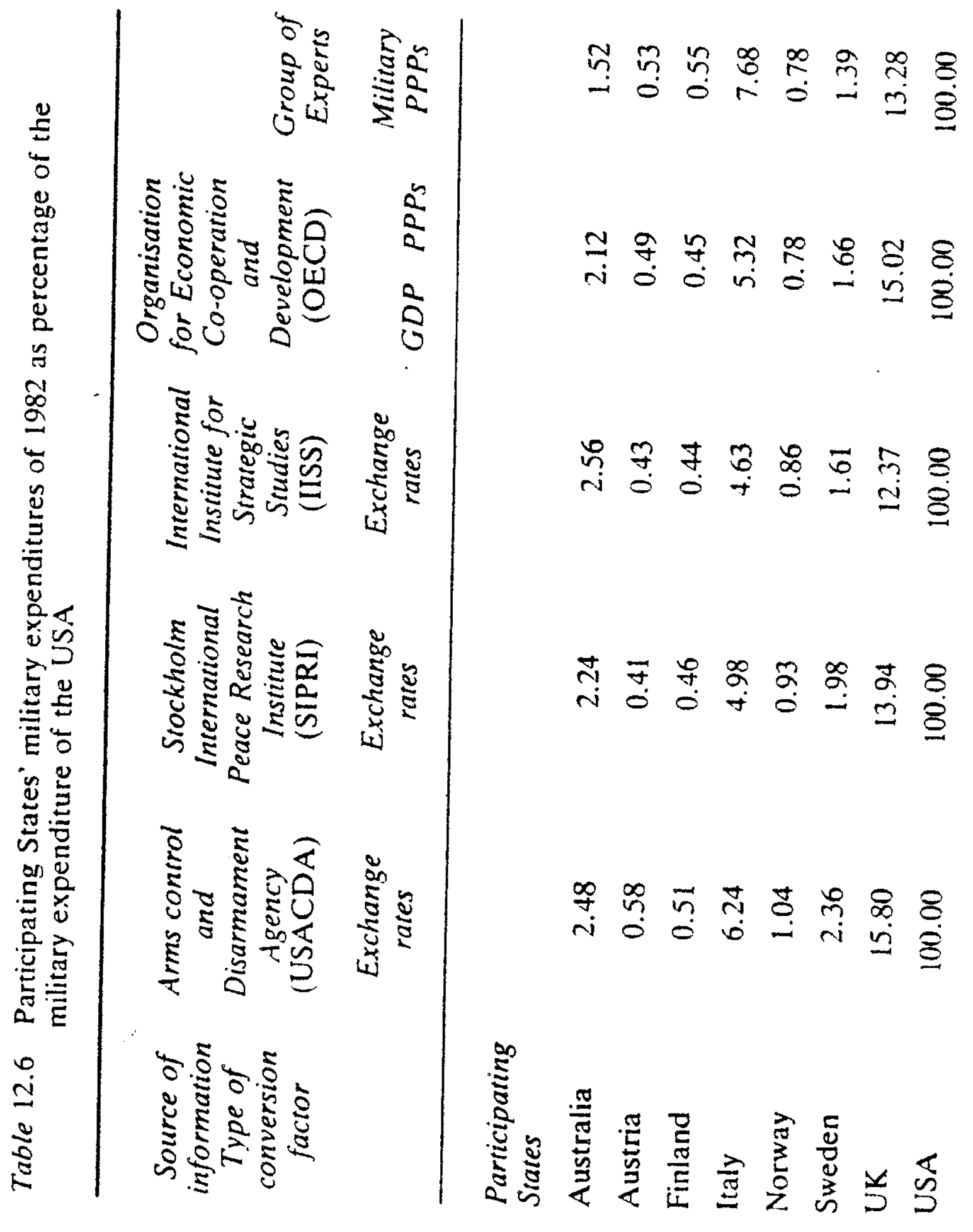


As shown by the results in Table 12.5 there were important differences both between military and civilian PPPs and between military PPPs and exchange rates. While the relations between military and civilian PPPs remained relatively stable over time their relations to exchange rates behaved very differently. As a result of the then-growing international value of the US dollar, exchange rates rose markedly in the years from 1980 to 1982. As the PPPs were not so much affected by the rise of the dollar, the relations between PPPs and exchange rates changed considerably in this short period, which clearly demonstrated the arbitrariness in selecting the exchange rates of one particular year as a tool for international comparisons.

The military PPPs constructed by the UN Group of Experts were used to compare the military expenditures of 1982 as reported to the United Nations by those countries which participated in the group's exercise. As shown in Table 12.6 the resulting figures were in turn compared with corresponding figures obtained from other sources. It may be noted that compared with those of other countries the US expenditure figure increased in all cases with the exception of Finland and Italy when military PPPs of 1982 were used instead of exchange rates of the same year. If the same kind of comparisons had been made a couple of years later, when the dollar rate had reached its peak, the opposite results would undoubtedly have been obtained. This again indicates that exchange rates should preferably not be used for international volume comparisons if other instruments, such as PPPs, are available.

\section{CONCLUDING REMARKS}

The PPP-method is by no means an easy way out. The construction of PPPs is a time-consuming and difficult task. Furthermore, it rests on the assumption that a reasonable amount of relevant statistical data can be made available which is not at all obvious in the field of military expenditures. Given political will and a reasonable availability of adequate and relevant information, the construction of useful instruments for international and intertemporal comparisons of military expenditures is feasible. 
Bibliography

EUROSTAT (1975), Comparisons of Real Values of the Aggregates of ESA, Luxemburg,

Fontanel, J.(1980). Le concept de dépenses militaires. Revue Défense Nationale,

Fontanel, J. (1981), L'estimation des dépenses militaires soviétiques, Arès, Défense et Sécurité.

Fontanel, J. (1982), Les comparaisons des dépenses militaires, Arès, Défense et Sécurité, novembre.

Fontanel, J., Smith, R. (1985) Analyse économique des dépenses militaires. Stratégique.

Fontanel, J., Smith, R. (1985), L'effort économique de Défense, Arès, Défense et Sécurité, $\mathrm{n}^{\circ}$ Spécial.

Fontanel, J, Smith, R (1985). "La comparaison des dépenses militaires de la France et du Royaume-Uni."Ares, Défense et Sécurité, $n^{\circ}$ spécial (1985).

Fontanel, J. (1987), A note on the International Comparison of Military Expenditures, in The Economics of Military Expenditures, Mac Millan, London.

Ivanov, Y, Ryzhov (1978), A new stage in the activities of the Council for Mutual Economic Assistance in the Field of International comparisons of National Product, Income and Wealth, March.

Kravis I.B.; Heston, A., Summers, R. (1978), International comparisons of Real Product and Purchansing power. John Hopkins University Press..

Kravis, I.B.; Heston, A., Summers, R. (1982), The international comparisons. Phase Project III, World Product and Income, international comparisons of GDP. John Hopkins University Press..

Salazar-Carrillo, J. (1973), Price, Purchasing Power and the Real product comparisons in Latin America, Income and Wealth, March.

United Nations (1976), Report of the Secretary-General: Reduction of Military Budgets-Measurements and International Reporting of Military Expenditures, A/31/222.

United Nations (1980), Report of the Secretary-General : Reduction of Military Budgets-Measurements and International Reportingof Military Expenditures, A/35/479.

United Nations (1982), Report of the Secretary-General : Reduction of Military Budgets-Measurements and International Reportingof Military Expenditures, A/S/12-7,

United Nations (1982), Report for the Group of Experts on the Reduction of Military Budgets, Working Paper n³. 11 March 1982.

United Nations (1985), Report of the Secretary-General: Reduction of Military Budgets- Construction of military price indexes and purchasing-power parities for comparison of Military Expenditures, A/40/421., 